\title{
The Rate of Liberation of Phosphate in Sea Water by the Breakdown of Plankton Organisms.
}

\author{
By \\ L. H. N. Cooper, \\ Assistant Chemist at the Plymouth Laboratory.
}

With One Figure in the Text.

IN the late spring of 1934 four experiments were started to determine how quickly inorganic phosphate may be set free from plankton. Samples of plankton caught in fine and very fine silk tow-nets were analyzed for phosphorus (Cooper, 1934) and aliquot parts were filtered on a silk disc having 200 meshes to the linear inch. The plankton was then added to two litre samples of fresh outside sea water in Winchester quart bottles. In all cases the amount of plankton initially present in the sample of sea water was less than $3 \%$ of that added.

In each experiment a sample of sea water untreated except for passage through butter muslin was kept as a control. The Winchester bottles, except in Experiment 1, were wrapped in black paper and all were stored in a cupboard away from light and shaken by hand at intervals. The mean temperature of the storage cupboard was about $14^{\circ} \mathrm{C}$. in April, $16^{\circ} \mathrm{C}$. in May and $19^{\circ} \mathrm{C}$. in June. At suitable times $100 \mathrm{ml}$. portions were removed from the well-shaken bottle and analysed for phosphate in the usual way (Denigès-Atkins method), except that samples enriched with plankton had first to be filtered through Zsigmondy membrane filters (filtration time, 20 seconds). Even so after a few weeks the colour match with standards in the phosphate analyses on these filtrates was not too good and the analyses are less accurate than those on ordinary sea water. The worst samples to compare were those rich in plants. All results are recorded as $\mathrm{mg}$. P. per cubic metre corrected, when necessary, for salt error.

\section{Experiments 1 and 2. Zooplankton.}

The sample of plankton used for Expt. 1 was mixed, consisting mostly of animals. That for Expt. 2 contained Calanus, some Acartia and Temora, a few Ctenophores and very little plant life.

The control to Expt. 1 after two months reached a maximum phosphate content greater than the preceding winter maximum in the 


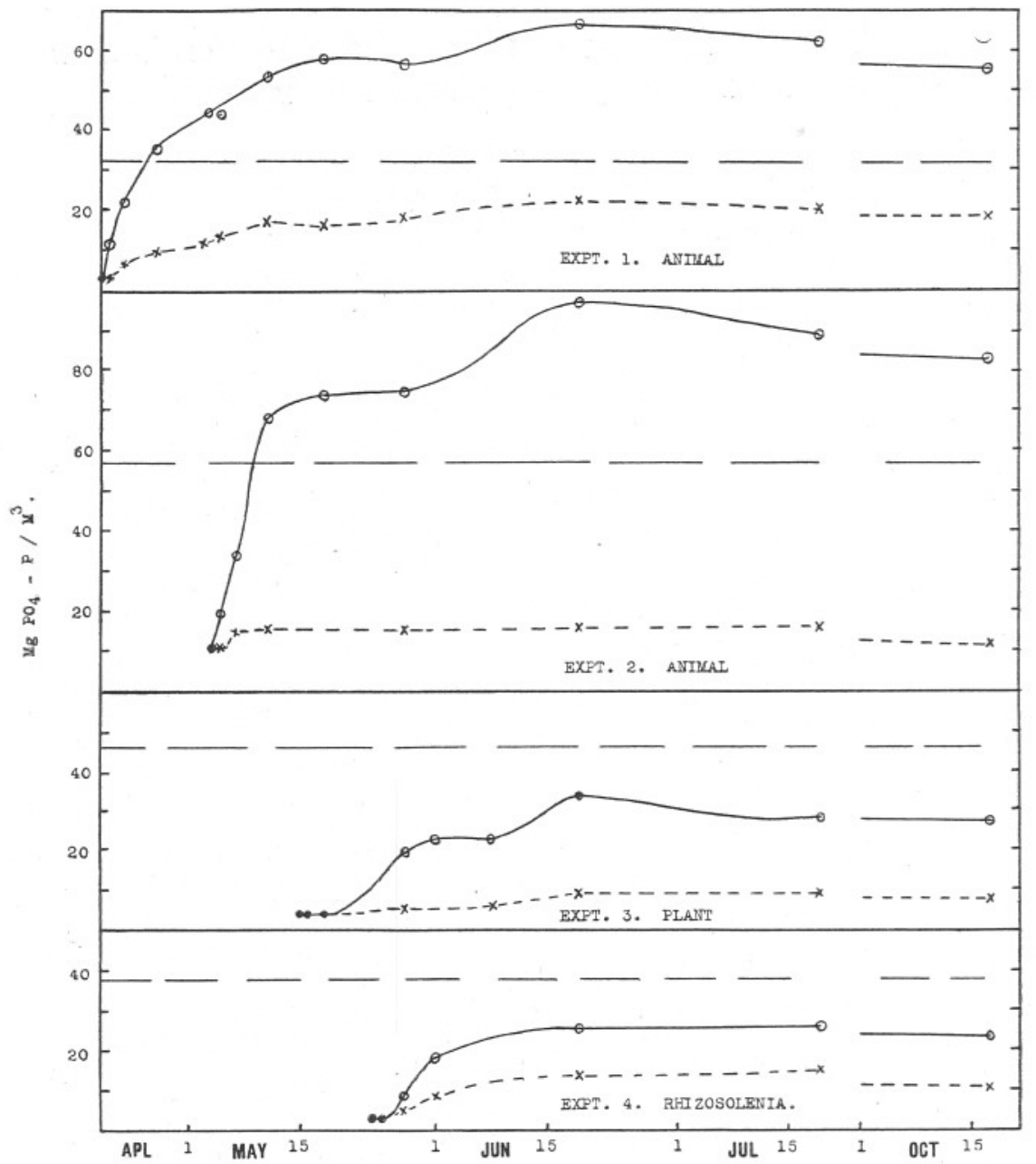

Fra. 1.-Liberation of Phosphate-phosphorus $\left(\mathrm{PO}_{4}-\mathrm{P}\right)$ by breakdown of plankton.

- - - - - - - -

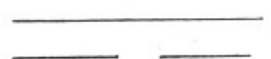

Controls.

With added plankton.

Sum of $\mathrm{PO}_{4}-\mathrm{P}$ initially present in the water and plankton-P added. 
English Channel. In the control to Expt. 2, however, the liberation of phosphate was much less. In the waters with added zooplankton (Expt. 1, $29 \mathrm{mg}$. and Expt. 2, 46.5 mg. per cubic metre of added phosphorus) the liberation of phosphate was very rapid, about $10 \mathrm{mg} . \mathrm{P}$ being set free in the first twelve hours and an amount equivalent to that added as plankton in about six days. Quite unexpectedly phosphate continued to be set free until the maximum was reached after about six weeks or two months. It was clear that about $40 \mathrm{mg}$. $\mathrm{P}$ per cubic metre was being rapidly set free from dissolved organic compounds present in the sea water. The results of Matthews (1917), Ibañez (unpublished), Kalle (1933) and Kreps (1934) show that sea water may contain 30-50 mg. of organic phosphorus per cubic metre which, however, may include some arsenic (Atkins and Wilson, 1927, and Rakestraw and Lutz, 1933).

\section{Experiments 3 and 4. Diatoms.}

The sample used for Expt. 3 was rich in diatoms, particularly Rhizosolenia spp. That for Expt. 4 was practically entirely diatoms; each litre of the experimental water contained 453,000 Rhizosolenia shrubsolei, $90,000 R$. fäeroensis, 28,000 Skeletonema costatum, and 6,200 Guinardia flaccida, equivalent to, say, 570,000 R. shrubsolei. Little else was present. I am indebted to Dr. Lebour for these counts made with the hemacytometer.

The control to Expt. 3 showed little change, but that to Expt. 4 in a month showed a rise of $12 \mathrm{mg}$. $\mathrm{P}$ per cubic metre. In the experiments with diatoms added, little happened for two or three days, in marked contrast to the behaviour of animal plankton, and then rapid liberation of phosphate took place, the maximum being reached in a month. Even at the maximum only part of the phosphorus added as phytoplankton had been set free to the water.

Two phenomena are common to most of the curves in Fig. 1. Firstly, an inflection is to be noted after 15-20 days' storage. The rate of liberation slowed down and then picked up again before reaching the maximum. Secondly, a slow fall in phosphate occurred in the four months after the maximum had been reached. No explanation is apparent for this, although moulds may play a part. The experimental waters were much richer in plankton than the sea ever is, so that presumably compared with natural conditions all processes of decay were much accelerated. A number of other experiments made under somewhat different conditions with the same catches of plankton served but to confirm the results here set forth.

The author is indebted to Mr. H. W. Harvey for suggesting this research and for his interest in its progress. 
TABLE I.

All Phospate Data as mg. P per Cubic Metre corrected for SALT ERror.

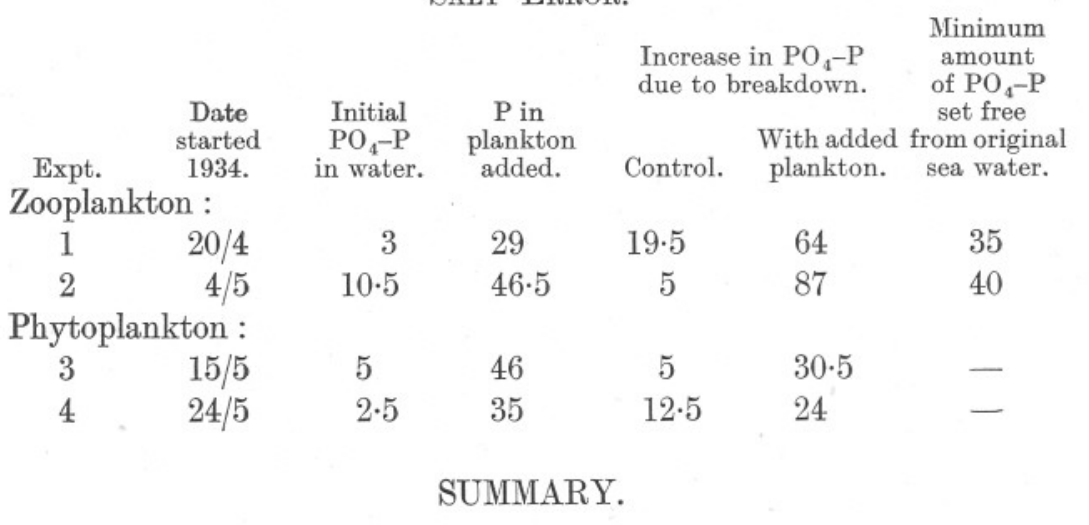

Samples of animal and plant plankton were added to sea water in glass vessels and the subsequent changes in the phosphate content of the water were followed.

The breakdown of the zooplankton was very rapid and more phosphate was set free than had originally been added as plankton. The balance was produced from dissolved organic phosphorus compounds in the water. The breakdown of phytoplankton showed a short time lag and only a part of the phosphorus added was set free as phosphate.

\section{REFERENCES.}

Atkins, W. R. G., and Wilson, E. G. 1927. The Phosphorus and Arsenic Compounds of Sea Water. Journ. Mar. Biol. Assoc., N.S., Vol. XIV, pp. 609-614.

Cooper, L. H. N. 1934. The Determination of Phosphorus and Nitrogen in Plankton. Journ. Mar. Biol. Assoc., N.S., Vol. XIX, pp. $755-759$.

Kalle, K. 1933. Phosphat und Gesamtphosphor in Beziehung zu Temperatur, Salzgehalt und Plankton an der Oberfläche der isländischen Küstengewässer. Ber. deutsch. Wiss. Komm. Meeresforschung, N.F., Vol. 6, pp. 273-299.

Kreps, E. 1934. Organic Catalysts or Enzymes in Sea Water. James Johnstone Memorial Volume. Liverpool, pp. 193-202.

Matrhews, D. J. 1917. On the Amount of Phosphoric Acid in the Sea Water off Plymouth Sound. II. Journ. Mar. Biol. Assoc., N.S., Vol. XI, pp. 251-257.

Rakestraw, N. W., and Lutz, F. B. 1933. Arsenic in Sea Water. Biol. Bull., Vol. 65, pp. 397-401. 